Al Maal : Journal of Islamic Economics and Banking

http://jurnal.umt.ac.id/index.php/jieb

E-ISSN : $2580-3816$

Vol : 2 No. 1 Bulan Juli Tahun 2020

Hlm : $\quad 49-62$

DOI : 10.31000/almaal.v2i1.2754

\title{
Pengaruh Kompetensi Sumber Daya Manusia Terhadap Tingkat Loyalitas Nasabah
}

\author{
Rahmawati Akeda $^{1^{*}}$, Harun Masykur ${ }^{2}$, Regita Cahyani ${ }^{3}$ \\ 1,2,3 Program Studi Perbankan Syari'ah, Fakultas Agama Islam, Universitas Muhammadiyah \\ Tangerang, Indonesia \\ *akedamath@gmail.com
}

\section{ABSTRACT}

This research aims to data This research aims to determine whether the influence of human resources competence on the level of customer loyalty in the BPRS Harta Insan Karimah branch Karawaci. This type of research is field research with a quantitative approach with 40 respondents. Data that is used is the result of the processing of answers respondents to the questionnaire that was shared by researchers to customers of PT. BPRS Harta Insan Karimah branch Karawaci. The results of this study concluded that the competency of human resources has a positive effect on the level of customer loyalty, as the test result obtained by $t$ Account of 4.886 is greater than the This IE 2.024 (4.886 > 2.024). Based on the test T shows a significant result of $0.000<0.05$ which means that human resource competence significantly affects the level of customer loyalty. Based on the results the correlation coefficient indicates a strong and positive relationship between the two variables and the result of the coefficient of determination can be known that independent variables describe the dependent variable by $38.6 \%$.

Keywords: Competence; Human Resources; Customer Loyalty.

\begin{abstract}
ABSTRAK
Penelitian ini bertujuan untuk mengetahui adakah pengaruh kompetensi sumber daya manusia terhadap tingkat loyalitas nasabah di BPRS Harta Insan Karimah Cabang Karawaci. Jenis penelitian ini adalah penelitian lapangan dengan pendekatan kuantitatif dengan 40 responden. Data yang digunakan adalah data hasil pengolahan jawaban responden terhadap kuesioner yang dibagikan peneliti kepada nasabah PT. BPRS Harta Insan Karimah Cabang Karawaci. Hasil penelitian ini menyimpulkan bahwa kompetensi sumber daya manusia berpengaruh positif terhadap tingkat loyalitas nasabah, sebagaimana hasil uji t diperoleh $t_{\text {hitung }}$ sebesar 4,886 lebih besar dari $t_{\text {tabel }}$ yaitu 2,024 (4,886 > 2,024). Berdasarkan uji t menunjukkan hasil signifikansi sebesar 0,000 < 0,05 yang berarti kompetensi sumber daya manusia berpengaruh signifikan terhadap tingkat loyalitas nasabah. Berdasarkan hasil koefisien korelasi menunjukkan adanya hubungan yang kuat dan positif antar dua variabel dan hasil koefisien determinasi dapat diketahui bahwa variabel independen menjelaskan variabel dependen sebesar 38,6\%.
\end{abstract}

Kata kunci : Kompetensi; Sumber Daya Manusia; Loyalitas Nasabah. 


\section{Pendahuluan}

Perkembangan Bank syariah juga diikuti dengan berkembangnya Bank Pembiayaan Rakyat Syariah (BPRS) yang turut serta berperan dalam kemajuan industri keuangan syariah di Indonesia. Direktur Grup Pengelolaan Transformasi LPS Suwandi mengatakan, penyebab utama banyaknya BPR dilikuidasi antara lain karena adanya fraud (kecurangan) yang terjadi di manajemen BPR maupun BPRS. BPR dan BPRS dilikuidasi bukan karena persaingan, bukan kalah karena program kredit usaha rakyat. Tapi hampir semuanya karena fraud, baik yang dilakukan pengurus, direksi, pegawai bank itu sendiri (Sitanggang, 2016). Fakta yang terjadi di lapangan ini menunjukkan tata kelola BPR dan BPRS masih sangat buruk dan banyak yang harus dibenahi.

Setiap perusahaan tentunya membutuhkan orang-orang yang kompeten untuk memajukan perusahaannya. Dunia yang didominasi sektor jasa, pentingnya modal manusia tidak dapat dipungkiri. Untuk mendapatkan pengembalian atas investasi (Return on Investment) sumber daya fisik dan teknologi, perusahaan sangat tergantung pada kompetensi pekerja. Dalam lingkup yang luas, modal manusia yang didefinisikan sebagai keterampilan, ketangkasan, dan pengetahuan sekelompok orang, merupakan penentu utama pertumbuhan ekonomi saat ini. Oleh karena itu, perusahaan harus berani melakukan upaya pengembangan kompetensi secara sistematis (Tho'in, 2016).

McAshan, mengemukakan kompetensi diartikan sebagai pengetahuan, keterampilan, dan kemampuan yang dikuasai oleh seorang yang telah menjadi bagian dari dirinya, sehingga ia dapat melakukan perilaku-perilaku kognitif, efektif, dan psikomotorik dengan sebaik-baiknya (Sutrisno, 2017). Perbaikan kualitas sumber daya manusia perlu diperhatikan lagi, masa depan industri perbankan syariah sangat bergantung pada pemenuhan sumber daya manusia, baik secara kualitas maupun kuantitas. Fakta di lapangan menyebutkan, setiap tahunnya industri perbankan syariah masih kekurangan sumber daya manusia yang mempuni dan sesuai kriteria. Disini terjadi ketimpangan antara permintaan pasar dengan sumber daya manusia yang tersedia.

Untuk memenuhi sumber daya manusia itu akhirnya dilakukan secara instan dengan cara memberikan pelatihan singkat kepada sumber daya manusia konvensional dan kemudian disalurkan ke industri perbankan syariah. Untuk mencetak sumber daya manusia yang berkualitas tentu diperlukan dukungan dari dunia pendidikan untuk membuka lebih banyak lagi program atau jurusan ekonomi dan perbankan syariah sehingga ketimpangan sumber daya manusia ini dapat teratasi. Dalam rangka peningkatan kompetensi dan mendorong kualitas sumber daya manusia, BPRS Harta Insan Karimah membuka kesempatan berkarir sebesar-besarnya bagi fresh graduate maupun yang sudah berpengalaman untuk meningkatkan kinerja perusahaan. Werther dan Davis, menyatakan bahwa sumber daya manusia adalah pegawai yang siap, mampu dan siaga dalam mencapai tujuan-tujuan organisasi. Sebagaimana dikemukakan bahwa dimensi pokok sisi sumber daya adalah kontribusinya terhadap organisasi, sedangkan dimensi pokok manusia adalah perlakuan kontribusi terhadapnya yang pada gilirannya akan menetukan kualitas dan kapabilitas hidupnya (Sutrisno, 2017).

Kualitas pelayanan dari sumber daya manusia yang berkompeten di lembaga keuangan syariah memiliki peranan penting dalam memberikan kepuasan kepada nasabah yang akan menjaga loyalitas nasabah. Sumber daya manusia yang profesional memiliki peranan penting dalam menciptakan pelayanan yang bermutu. Tolak ukur loyalitas dapat dilihat dari kesesuaian antara harapan nasabah dengan pelayanan yang diberikan. 
Masalah-masalah sumber daya manusia yang terjadi dapat menghambat peningkatan loyalitas nasabah. Loyalitas didefinisikan sebagai komitmen yang dipegang kuat untuk membeli atau berlangganan lagi produk atau jasa tertentu di masa depan meskipun ada pengaruh situasi dan usaha pemasaran yang berpotensi menyebabkan perubahan perilaku (Mandong, Tumbel \& Tawas, 2017). Loyalitas nasabah juga dipengaruhi oleh proses psikologis terdiri dari pengolahan informasi, pembelajaran, perubahan sikap atau perilaku nasabah itu sendiri. Menurut Hawkins dan Mothersbaugh, model perilaku konsumen berpusat pada konsep diri (self-concept) dan gaya hidup, yang terbentuk sebagai hasil pengaruh berbagai faktor internal (psikologis dan fisik) dan eksternal (sosiologis dan demografis). Konsep diri dan gaya hidup ini kemudian menghasilkan kebutuhan dan keinginan yang perlu dipuaskan relevan, maka proses keputusan konsumen dimulai (Suherman \& Tjiptono, 2019).

Lembaga keuangan syariah sangat perlu untuk melakukan pengembangan kompetensi sumber daya manusia agar kualitas pelayanan dapat terus ditingkatkan. Strategi pengembangan sumber daya manusia syariah dalam jangka panjang. Dengan begitu diharapkan kompetensi sumber daya manusia di lembaga keuangan syariah mampu meningkatkan mutu pelayanan secara tepat dan efisien, sehingga mampu meningkatan loyalitas nasabah. PT. Bank Pembiayaan Rakyat Syariah Harta Insan Karimah sebagai salah satu bank pembiayaan rakyat syariah terbaik di Indonesia dengan berbagai penghargaan yang telah diraih salah satunya, penghargaan dari Sharia Finance Awards 2016 sebagai "BPRS Predikat Sangat Bagus" versi Majalah Infobank. Adapun penelitian ini untuk mengetahui bagaimana tata kelola bank di BPRS tersebut sehingga dapat mengembangkan sumber daya manusia dengan baik dan mampu menjaga eksistensi serta loyalitas nasabahnya. Hasil dari pemaparan latar belakang diatas maka peneliti tertarik untuk mengkaji masalah tersebut dan menuangkannya dalam penelitian yang berjudul "Pengaruh Kompetensi Sumber Daya Manusia Terhadap Tingkat Loyalitas Nasabah di PT. BPRS Harta Insan Karimah Cabang Karawaci”.

\section{KAJIAN LITERATUR Kompetensi}

Menurut Sutrisno (2017), secara harfiah kompetensi berasal dari kata competence yang artinya kecakapan, kemampuan, dan wewenang. Adapun secara etimologi, kompetensi diartikan sebagai dimensi perilaku keahlian atau keunggulan seorang pemimpin atau staf yang mempunyai keterampilan, pengetahuan, dan perilaku yang baik.

Kompetensi adalah suatu kemampuan yang dilandasi oleh keterampilan dan pengetahuan yang didukung oleh sikap kerja serta penerapannya dalam melaksanakan tugas dan pekerjaan di tempat kerja yang mengacu pada persyaratan kerja yang diterapkan. Kompetensi merupakan variabel utama yang harus dimiliki oleh seorang karyawan dalam melaksanakan pekerjaannya, sehingga dengan adanya kompetensi yang telah dimiliki dapat membantu para karyawan didalam menyelesaikan pekerjaan sesuai dengan target yang telah ditentukan (Rivai \& Sagala, 2013).

Kompetensi sumber daya manusia untuk setiap usaha berbeda-beda, kompetensi yang dibutuhkan, untuk Lembaga keuangan Syariah, Gita (2013) menjelaskan bahwa kunci kompetensi pengembangan sumber daya manusia memiliki banking knowledge (ilmu perbankan), immediate result (produktifitas), syariah knowledge (pengetahuan 
syariah), attitude and behavior (sikap dan kebiasaan) dan managerial skill (kemampuan memimpin), semua kompetensi tersebut harus dipadukan dengan pengembangan sifat Rasullah SAW yaitu sidiq (jujur), amanah (dapat dipercaya), tabligh (transparan), fathonah (professional). Secara empirik, sikap dan prilaku (attitude and behavior) bagian dari kompetensi sumber daya manusia pegawai bank pun salah satu yang mempengaruhi nasabah loyal (Roman, 2003).

\section{Sumber daya Manusia}

Semula SDM merupakan terjemahan dari "human resources", namun ada pula ahli yang menyamakan sumber daya manusia dengan "manpower" (tenaga kerja). Sumber daya manusia merupakan satu-satunya yang memiliki akal perasaan, keinginan, keterampilan, pengetahuan, dorongan, daya, dan karya (rasio, rasa, dan karsa). Betapapun majunya teknologi, perkembangan informasi, tersedianya modal dan memadainya bahan, jika tanpa SDM sulit bagi organisasi itu untuk mencapai tujuannya (Sutrisno, 2017). Sumber daya manusia adalah tenaga kerja yang menduduki suatu posisi atau orang-orang yang mempunyai tanggung jawab untuk melaksanakan tugas atau pekerjaan pada suatu organisasi tertentu (Almasri, 2016). Mc. Lelland kompetensi merupakan karakteristik dasar personel yang menjadi faktor penentu sukses tidaknya seseorang dalam mengerjakan suatu pekerjaan atau pada situasi tertentu (Moeheriono, 2012).

Sumber daya manusia dalam prespektif Islam dapat merujuk pada firman Allah SWT dalam Q.S At-Tiin (95): 4-6 yaitu:

"Sesungguhnya Kami telah menciptakan manusia dalam bentuk yang sebaikbaiknya. Kemudian Kami kembalikan dia ke tempat yang serendah-rendahnya. Kecuali orang-orang yang beriman dan mengerjakan amal saleh; maka bagi mereka pahala yang tiada putus-putusnya."

Allah SWT berfirman dalam surah al-Mujadalah (58):11 yaitu:

Wahai orang-orang yang beriman, apabila dikatakan kepadamu, berilah kelapangan di dalam majelis-majelis, maka lapangkanlah. Niscaya Allah Swt. Akan memberi kelapangan untukmu. Apabila dikatakan, berdirilah kamu, maka berdirilah. Niscaya Allah SWT. Akan mengangkat (derajat) orang-orang yang beriman di antaramu dan orang-orang yang diberi ilmu beberapa derajat. Allah SWT. Maha teliti apa yang kamu kerjakan."

Kedua firman Allah SWT diatas kita dapat mendefinisikan sumber daya manusia Islam adalah sumber daya yang memiliki keimanan kepada Allah serta rasul-Nya, memiliki ilmu pengetahuan dan berakhlak sesuai ketentuan Al-Qur'an dan Sunnah.

\section{Loyalitas}

Loyalitas menurut Tjiptono (2000) adalah situasi dimana nasabah bersikap positif terhadap produk atau produsen (penyedia jasa/produk) dan disertai pola pembelian ulang yang konsisten.

Loyalitas merupakan kesetiaan yang tercermin dari kepuasan pelanggan, Jennie menyatakan bahwa pelanggan yang setia adalah mereka yang sangat puas dengan produk tertentu sehingga mempunyai antusiasme untuk memperkenalkan kepada siapa pun yang mereka kenal. Selanjutnya pada tahap berikutnya pelanggan yang loyal tersebut akan memperluas "kesetiaan" mereka pada produk lain buatan produsen yang sama. Pada 
akhirnya mereka adalah kosumen yang setia kepada produsen tertentu untuk selamanya (Wijayanto, 2015).

Jacky (2007) menjelaskan bahwa loyalitas pelanggan harus dibangun saat pelanggan mulai menjadi suspek (suspect), kemudian meningkat menjadi prospek (prospect), dan kemudian meningkat lagi menjadi pembeli pertama (first time buyer), pelanggan loyal (loyal client), dan akhirnya menjadi pelanggan yang antusias (spiritual advocate), agar pelanggan loyal maka perusahaan harus memiliki produk yang memiliki keunggulan, pelayanan bermutu, membentuk brand produk yang baik, membangun komunitas dan memberikan benefit tambahan lainya.

\section{Strategi Meningkatkan Loyalitas Nasabah}

Menurut Lupiyoadi (2001), dalam meningkatkan kepuasan nasabah atau loyalitas nasabah ada lima faktor yang perlu diperhatikan yaitu:

1) Kualitas Produk

Nasabah akan merasa puas jika membeli dan menggunakan produk tersebut dan kualitasnya baik. Terdapat enam elemen dalam kualitas produk yaitu: performance, durability, feature, reliability, consistency dan design.

\section{2) Harga}

Bagi nasabah yang sensitif harga yang lebih murah adalah sumber kepuasan terpenting, karena mereka akan mendapatkan value money yang tinggi. Komponen ini sangat penting bagi beberapa perusahaan yang ingin menciptakan kepuasan konsumen.

\section{3) Service Quality}

Komponen ini terdiri dari tiga hal yaitu sistem, teknologi dan manusia. Faktor manusia memegang kontribusi terbesar.

4) Emotional Factor

Komponen ini berlaku untuk nasabah dengan gaya hidup seperti: mobil, pakaian, kosmetik dan sebagainya. Rasa bangga, simbol sukses dan rasa percaya diri, bagian orang penting dan sebagainya adalah contoh-contoh emotional value yang mendasari kepuasan nasabah.

5) Biaya dan Kemudahan mendapatkan Produk

Pelanggan akan merasa puas jika biaya dan produk yang diperoleh relatif mudah, nyaman, dan efisien dalam mendapat produk atau pelayanan.

\section{Metode Penelitian Jenis Penelitian}

Adapun metode yang penulis gunakan dalam penelitian ini adalah metode deskriptif kuantitatif. Sugiyono (2017) pengertian metode penelitian adalah metode penelitian dapat diartikan sebagai cara ilmiah untuk mendapatkan data yang valid dengan tujuan dapat ditemukan, dikembangkan dan dibuktikan, suatu pengetahuan tertentu sehingga pada gilirannya dapat digunakan untuk memahami, memecahkan dan mengantisipasi masalah. 


\section{Populasi dan Sampel}

Populasi adalah seluruh subjek di dalam wilayah penelitian dijadikan subjek penelitian sedangkan sampel yaitu hanya sebagian dari subjek penelitian yang dipilih dan dianggap mewakili keseluruhan. Dalam pengambilan sampel harus selalu diingat bahwa tujuannya adalah untuk membuat kesimpulan sifat populasi berdasarkan sifat sampel (Sumanto, 2014). Pengambilan sampel dalam penelitian ini sebanyak 40 orang.

\section{Teknik Pengumpulan Data}

Menurut Sugiyono (2010) kuesioner merupakan teknik pengumpuan data yang diakukan dengan cara memberi seperangkat pertanyaan atau pertanyaan tertulis kepada responden untuk dijawabnya. Untuk mengetahui strategi meningkatkan kompetensi sumber daya manusia dan loyalitas nasabah maka dilakukan wawancara dengan pihak PT. BPRS Harta Insan Karimah Cabang Karawaci.

\section{Analisis Data}

Adapun analisis data yang dilakukan peneliti diawali dengan melakukan uji persyaratan analisis dengan uji validitas, uji reliabilitas, uji asumsi klasik, uji regresi sederhana dan uji t. Nasabah yang menjadi responden paling banyak dalam penelitian ini yaitu anggota guru dari sekolah di sekitar kota Tangerang yang memiliki kerja sama dengan PT. BPRS Harta Insan Karimah Cabang Karawaci

\section{Hasil dan PEMbahasan Data Responden}

Responden penelitian akan diuraikan secara deskriptif dan dibantu dengan penyajian dalam bentuk tabel dari jumlah responden dengan dibagi kedalam beberapa tabel yaitu jenis kelamin, kelompok usia, pendidikan terakhir dan berdasarkan pekerjaan.

Tabel 1. Responden berdasarkan jenis kelamin

\begin{tabular}{llll}
\hline No. & Jenis Kelamin & Responden & Persentase (\%) \\
\hline 1 & Laki-laki & 8 & $20 \%$ \\
2 & Perempuan & 32 & $80 \%$ \\
Jumlah & 40 & $100 \%$ \\
\hline \multicolumn{3}{c}{ Sumber: data diolah dengan SPSS 24}
\end{tabular}

Pada tabel diatas dapat diketahui dari 40 orang bahwa yang berjenis kelamin lakilaki sebanyak 8 orang $(20 \%)$ dan jumlah responden yang berjenis kelamin perempuan sebanyak 32 orang $(80 \%)$.

Tabel 2. Responden berdasarkan usia

\begin{tabular}{llll}
\hline \multicolumn{1}{c}{ No. } & \multicolumn{1}{c}{ Usia } & \multicolumn{1}{c}{ Responden } & Persentase (\%) \\
\hline 1 & $21-30$ tahun & 8 & $20 \%$ \\
2 & $31-40$ tahun & 13 & $32,5 \%$ \\
3 & $41-50$ tahun & 11 & $27,5 \%$ \\
4 & $51-60$ tahun & 8 & $20 \%$ \\
Jumlah & & 40 & $100 \%$ \\
\hline
\end{tabular}


Pada tabel diatas dapat diketahui nasabah yang menjadi responden untuk usia 21 - 30 tahun sebanyak 8 orang (20\%), usia 31 - 40 tahun sebanyak 13 orang (32,5\%), usia $41-50$ tahun sebanyak 11 orang $(27,5 \%)$ dan usia $51-60$ tahun sebanyak 8 orang $(20 \%)$.

Tabel 3. Responden berdasarkan pendidikan terakhir

\begin{tabular}{llll}
\hline No. & $\begin{array}{c}\text { Pendidikan } \\
\text { Terakhir }\end{array}$ & Responden & Persentase (\%) \\
\hline 1 & $S 2$ & 1 & $2,5 \%$ \\
2 & $S 1$ & 33 & $82,5 \%$ \\
3 & SMA/SMK & 6 & $15 \%$ \\
Jumlah & \multicolumn{4}{c}{$100 \%$} \\
\hline \multicolumn{4}{c}{ Sumber: data diolah dengan SPSS 24 }
\end{tabular}

Pada tabel diatas dapat diketahui bahwa responden terbanyak yaitu nasabah yang memiliki latar belakang pendidikan S1 yaitu sebanyak 33 orang $(82,5 \%)$, kemudian SMA/SMK sebanyak 6 orang $(15 \%)$ dan yang paling sedikit yaitu S2 sebanyak 1 orang $(2,5 \%)$.

Tabel 4. Responden berdasarkan pekerjaan

\begin{tabular}{llll}
\hline \multicolumn{1}{c}{ No. } & \multicolumn{1}{c}{ Pekerjaan } & Responden & Persentase (\%) \\
\hline 1 & PNS & 22 & $55 \%$ \\
2 & Non PNS & 14 & $35 \%$ \\
3 & Mahasiswa & 4 & $10 \%$ \\
Jumlah & \multicolumn{3}{c}{ Sumber: data diolah dengan SPSS 24 }
\end{tabular}

Pada tabel diatas dapat diketahui pekerjaan nasabah yang menjadi responden dalam penelitian ini. Nasabah yang bekerja sebagai PNS sebanyak 22 orang (55\%), Non PNS sebanyak 14 orang (35\%) dan mahasiswa sebanyak 4 orang (10\%).

\section{Hasi Uji Validitas dan Uji Reliabilitas}

\section{Uji Validitas}

Uji validitas digunakan untuk menunjukkan sejauh mana mutu alat ukur mampu mengukur apa yang akan diukur. Uji validitas pada penelitian ini menggunakan rumus koefisien korelasi Pearson Product Moment. Teknik pengujian dilakukan dengan cara mengkorelasikan skor-skor tiap butir pernyataan dengan skor total dari butir pernyataan,

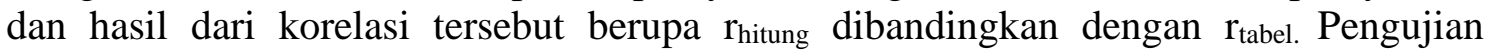
instrumen menggunakan uji dua sisi taraf signifikan 5\% dengan jumlah responden sebanyak 40 orang. Maka diketahui $\mathrm{df}=\mathrm{N}-2$ dengan probabilitas 0,05 sehingga nilai $\mathrm{r}_{\text {tabel }}$ adalah 0,312. Adapun kaidah pengujian validitas instrumen adalah suatu data dinyatakan valid jika $r_{\text {hitung }}>r_{\text {tabel }}(\alpha=5 \% ; n-2)$ dan $n=$ jumlah sampel (Sugiyono, 2009).

Tabel 5. Data uji validitas

\begin{tabular}{lllll}
\hline No. & Indikator & $r_{\text {hitung }}$ & Keterangan \\
\hline
\end{tabular}

1. Kompetensi Sumber Daya Manusia 


\begin{tabular}{|c|c|c|c|c|}
\hline No. & Indikator & $r_{\text {hitung }}$ & $r_{\text {tabel }}$ & Keterangan \\
\hline & $X .1$ & 0,736 & 0,312 & Valid \\
\hline & $X .2$ & 0,572 & 0,312 & Valid \\
\hline & $X .3$ & 0,572 & 0,312 & Valid \\
\hline & $X .4$ & 0,680 & 0,312 & Valid \\
\hline & $X .5$ & 0,805 & 0,312 & Valid \\
\hline & $X .6$ & 0,494 & 0,312 & Valid \\
\hline & $X .7$ & 0,491 & 0,312 & Valid \\
\hline & $X .8$ & 0,625 & 0,312 & Valid \\
\hline & $X .9$ & 0,533 & 0,312 & Valid \\
\hline & $X .10$ & 0,813 & 0,312 & Valid \\
\hline 2. & \multicolumn{4}{|c|}{ Tingkat Loyalitas Nasabah } \\
\hline & $Y .1$ & 0,503 & 0,312 & Valid \\
\hline & $Y .2$ & 0,499 & 0,312 & Valid \\
\hline & $Y .3$ & 0,605 & 0,312 & Valid \\
\hline & $Y .4$ & 0,564 & 0,312 & Valid \\
\hline & $Y .5$ & 0,487 & 0,312 & Valid \\
\hline & $Y .6$ & 0,488 & 0,312 & Valid \\
\hline & $Y .7$ & 0,479 & 0,312 & Valid \\
\hline & $Y .8$ & 0,660 & 0,312 & Valid \\
\hline & $Y .9$ & 0,614 & 0,312 & Valid \\
\hline & $Y .10$ & 0,540 & 0,312 & Valid \\
\hline
\end{tabular}

Sumber: data diolah dengan SPSS 24

Dari tabel hasil uji validitas di atas menunjukkan bahwa nilai masing-masing variabel kompetensi sumber daya manusia $(\mathrm{X})$ dan variabel tingkat loyalitas nasabah (Y) dinyatakan valid karena $r_{\text {hitung }}>r_{\text {tabel }}$ yaitu nilai korelasi diatas 0,312. Maka dapat disimpulkan bahwa semua pernyataan kuesioner dari variabel $\mathrm{X}$ dan $\mathrm{Y}$ dinyatakan valid.

\section{Uji Reliabilitas}

Uji reliabilitas digunakan untuk mengukur suatu kuesioner yang merupakan indikator dari suatu variabel. Reliabilitas diukur dengan uji statistik Cronbach's Alpha $(\alpha)$. Kaidah pengujian adalah suatu instrumen dinyatakan reliabel jika nilai Cronbach's Alpha > 0,60 (Ghozali, 2006). Pengukuran koefisien Cronbach's Alpha diakukan dengan menggunakan SPSS versi 24. Berikut ini merupakan hasil uji reliabilitas.

Tabel 6. Hasil uji reliabilitas

\begin{tabular}{llccl}
\hline No & \multicolumn{1}{c}{ Variabe } & $\begin{array}{c}\text { Cronbach } \\
\text { Alpha }\end{array}$ & $\begin{array}{c}\text { Cronbach } \\
\text { Alpha yang } \\
\text { diisyaratkan }\end{array}$ & Keterangan \\
\hline 1 & $\begin{array}{l}\text { Kompetensi } \\
\text { Sumber Daya } \\
\text { Manusia }\end{array}$ & 0,835 & $>0,60$ & Reliabel \\
& & & & \\
& $\begin{array}{l}\text { Tingkat } \\
\text { Loyalitas } \\
\text { Nasabah }\end{array}$ & 0,732 & $>0,60$ & Reliabel \\
\hline
\end{tabular}

Sumber: data diolah dengan SPSS 24 
Berdasarkan tabel data diatas menggunakan SPSS versi 24, menunjukkan hasil uji Cronbach's Alpha > 0,60 yaitu 0,835 dan 0,732 melebihi angka signifikan 0,60. Maka dapat disimpulkan bahwa setiap variabel yang diujikan adalah reliabel.

\section{Uji Normalitas}

Uji normalitas bertujuan untuk menguji apakah dalam model regresi, variabel terikat dan variabel bebas keduanya mempunyai distribusi normal atau tidak. Model regresi yang baik adalah memiliki distribusi normal atau mendekati normal. Untuk mengkaji apakah distribusi data normal atau tidak, salah satu cara untuk melihat normalitas adalah melihat uji statistik One Sample Kolmogorov-Smirnov yakni nilai uji $\mathrm{K}-\mathrm{S}>$ dibandingkan taraf signifikan 0,05

Tabel 7. Hasil uji normalitas Kolmogorov-Smirnov

\begin{tabular}{lll}
\hline \multicolumn{2}{c}{ One-Sample Kolmogorov-Smirnov Test } \\
& & $\begin{array}{c}\text { Unstandardized } \\
\text { Residual }\end{array}$ \\
\hline$N$ & & 40 \\
Normal Parameters ${ }^{a, b}$ & Mean &, 0000000 \\
& Std. Deviation &, 00652982 \\
Most Extreme Differences & Absolute &, 091 \\
& Positive &, 091 \\
& Negative &,- 071 \\
Test Statistic & &, 091 \\
Asymp. Sig. (2-tailed) & &, $200^{c, d}$ \\
\hline
\end{tabular}

Sumber: Output SPSS versi 24

Dari hasil pengujian One Sample Kolmogorov-Smirnov pada tabel 4.10 di atas menunjukkan bahwa besarnya probabilitas yang dilihat dari nilai signifikansi asymp. Sig. (2-tailed) sebesar 0,200. Karena signifikansi lebih besar dari 0,05 maka data tersebut berdistribusi normal.

\section{Uji Linearitas}

Uji linearitas bertujuan untuk apakah dua variabel mempunyai hubungan yang linear atau tidak secara signifikan. Uji ini biasanya digunakan sebagai prasyarat dalam analisis korelasi atau regresi linear. Pengujian pada SPSS dengan menggunakan Test For Linearity dengan pada taraf signifikan 0,05. Dua variabel dikatakan mempunyai hubungan yang linear bila signifikansi (Deviation From Linearity) > dari 0,05 (Ghozali, 2006). 
Tabel 8. Hasil uji linearitas

\begin{tabular}{|c|c|c|c|c|c|c|c|}
\hline \multicolumn{8}{|c|}{ ANOVA Table } \\
\hline & & & $\begin{array}{l}\text { Sum } \\
\text { Squares }\end{array}$ & $D f$ & $\begin{array}{l}\text { Mean } \\
\text { Square }\end{array}$ & $F$ & Sig. \\
\hline Tingkat & Between & (Combined) &, 002 & 13 &, 000 & 2,709 &, 015 \\
\hline Loyalitas & Groups & Linearity &, 001 & 1 & , 001 & 21,617 & , 000 \\
\hline Nasabah & & Deviation & ,001 & 12 & , 000 & ,967 & ,503 \\
\hline Kompetens & & from & & & & & \\
\hline$i \quad$ Sumber & & Linearity & & & & & \\
\hline Daya & Within $G$ & Groups & ,001 & 26 & , 000 & & \\
\hline Manusia & Total & &, 003 & 39 & & & \\
\hline
\end{tabular}

Sumber: Output SPSS versi 24

Berdasarkan tabel uji linearitas diketahui hasil nilai sig deviation from linearity sebesar 0,503 > 0,05 maka dapat disimpulkan bahwa terdapat hubungan yang linear antara kompetensi sumber daya manusia terhadap tingkat loyalitas nasabah.

\section{Uji Heteroskedatisitas}

Heteroskedastisitas adalah keadaan yang mana dalam model regresi terjadi ketidaksamaan variansi dari residual pada satu pengamatan ke pengamatan yang lain. Hasil probabilitas dikatakan signifikan jika nilai signifikansinya diatas tingkat kepercayaan 5\% (Ghozali, 2013).

Tabel 9. Hasil uji heteroskedastisitas menggunakan uji glejser

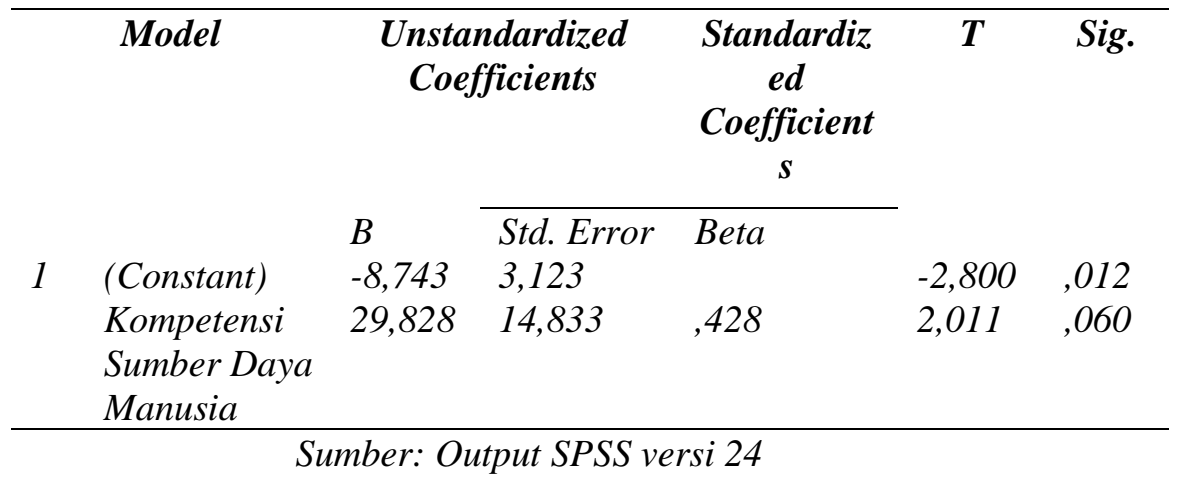

Pada tabel output hasil uji heteroskedastisitas menggunakan uji glejser. Pada kotak Coefficients terlihat kompetensi sumber daya manusia (X) memiliki nilai sig. 0,60. Nilai sig. 0,60>0,05 artinya tidak terjadi heteroskedastisitas.

\section{Analisis Regresi Sederhana}

Analisis regresi sederhana digunakan untuk mengetahui arah hubungan diantara kedua variabel, serta menguji pengaruh variabel bebas terhadap variabel terikat. Dasar pengambilan keputusan dalam analisis regresi yaitu: jika nilai sig. $<0,05$ maka terdapat pengaruh variabel $X$ terhadap variabel $Y$. Sebaliknya jika nilai sig. $>0,05$ maka tidak terdapat pengaruh antara variabel X terhadap variabel Y (Raharjo, 2019). Berdasarkan perhitungan menggunakan aplikasi SPSS versi 24 diperoleh data sebagai berikut: 
Tabel 10. Hasil uji regresi linear sederhana

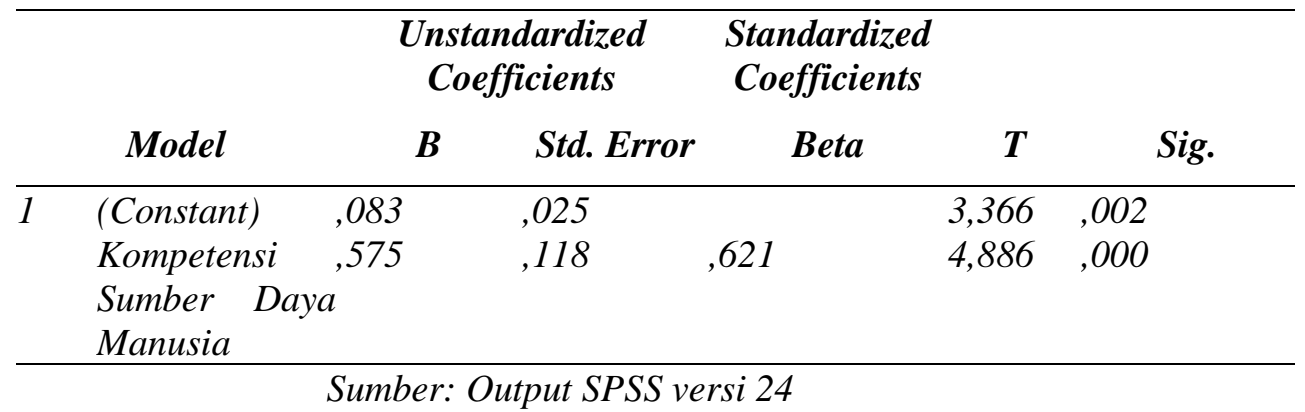

Berdasarkan tabel di atas nilai sig. $(0,000)<0,05$ maka terdapat pengaruh yang signifikan antara kompetensi sumber daya manusia terhadap tingkat loyalitas nasabah. Diperoleh pula persamaan regresi sederhana sebagai berikut:

$$
\begin{aligned}
& Y=a+b X \\
& Y=0,083+0,575 X
\end{aligned}
$$

Dari persamaan tersebut dapat diketahui bahwa:

Konstanta sebesar 0,083 artinya jika kompetensi sumber daya manusia (X) nilainya 0 (nol) atau tidak ada kompetensi sumber daya manusia maka, tingkat loyalitas nasabah (Y) adalah sebesar 0,083.

Koefisien regresi kompetensi sumber daya manusia (X) mempengaruhi tingkat loyalitas nasabah sebesar 0,575 atau berpengaruh positif yang artinya jika kompetensi sumber daya manusia mengalami peningkatan $1 \%$ maka akan diikuti oleh tingkat loyalitas nasabah sebesar 0,575 .

\section{Koefisien Determinasi}

Uji koefisien determinasi digunakan untuk mengetahui seberapa jauh variabel bebas dapat menjelaskan variabel terikat, maka perlu diketahui nilai koefisien determinasinya. Koefisien determinasi $\left(\mathrm{R}^{2}\right)$ berkisar antara nol sampai dengan satu $(0 \leq$ $\left.\mathrm{R}^{2} \leq 1\right)$ (Kadir, 2015). Bila $\mathrm{R}^{2}$ semakin besar mendekati 1 menunjukkan semakin besar pengaruh variabel independen terhadap variabel dependen dan bila $\mathrm{R}^{2}$ mendekati 0 , maka semakin kecil pula pengaruh variabel independen terhadap variabel dependen. Berikut ini hasil perhitungan data koefisien determinasi menggunakan aplikasi SPSS versi 24:

Tabel 11. Hasil Uji Koefisien Determinasi

\begin{tabular}{lllll}
\hline Model & $\boldsymbol{R}$ & $\boldsymbol{R}$ Square & Adjusted $\boldsymbol{R}$ Square & $\begin{array}{c}\text { Std. Error of the } \\
\text { Estimate }\end{array}$ \\
\hline 1 &, $621^{a}$ &, 386 &, 370 &, 00662 \\
\hline \multicolumn{4}{c}{ Sumber: Output SPSS versi 24}
\end{tabular}

Berdasarkan tabel diatas hasil R-Square menunjukkan bahwa nilai koefisien determinasi sebesar 0,386 atau 38,6\%. Hal ini menunjukkan bahwa variabel kompetensi sumber daya manusia (X) berkontribusi terhadap tingkat loyalitas nasabah (Y) sebesar $38,6 \%$ dan sisanya $61,4 \%$ dipengaruhi oleh variabel lain yang tidak diteliti dalam penelitian ini. 


\section{Uji t} berikut:

Berikut ini adalah hasil perhitungan uji t menggunakan SPSS versi 24 sebagai

Tabel 12. Hasil Uji T

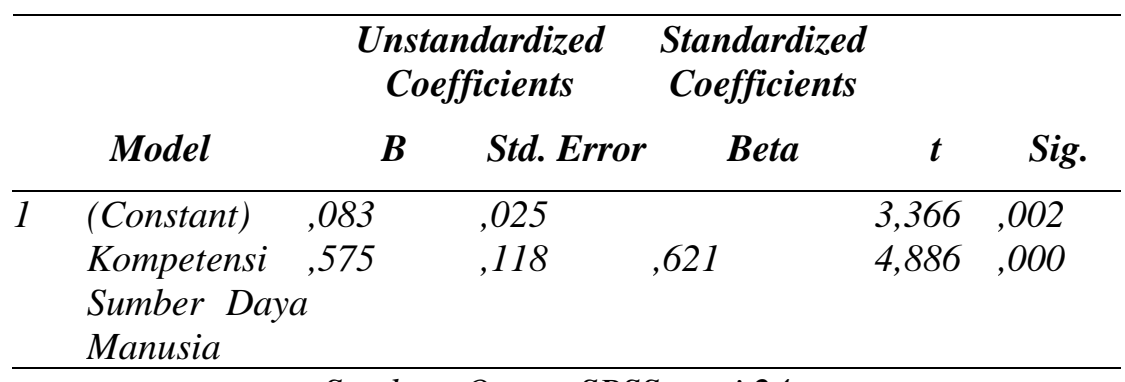

Sumber: Output SPSS versi 24

Dasar pengambilan keputusan apabila nilai signifikansi < probabilitas 0,05 dan nilai $t_{\text {hitung }}>\mathrm{t}_{\text {tabel }}$ maka artinya terdapat pengaruh anatara kompetensi sumber daya manusia terhadap tingkat loyalitas nasabah (Raharjo, 2019). Berdasarkan tabel 4.16 di atas diperoleh hasil thitung sebesar 4,886 lebih besar dari tabel yaitu 2,024 $(4,886>2,024)$ dan nilai signifikansi lebih kecil dari $\alpha(0,000<0,05)$ maka hipotesis diterima, terdapat pengaruh yang positif dan signifikan antara kompetensi sumber daya manusia terhadap tingkat loyalitas nasabah.

Implikasi manajerial dari hasil penelitian ini, BPRS HIK harus menguatkan kompetensi SDM nya guna meningkatkan loyalitas nasabah dengan cara meningkatkan sikap dan prilaku sesuai syariah, memiliki pengetahuan syariah yang sangat baik,pengetahuan operasional bank syariah yang sangat baik, semua hal itu digunakan saat nasabah menjadi suspek (suspect), kemudian meningkat menjadi prospek (prospect), dan kemudian meningkat lagi menjadi pembeli pertama atau nasabah (fist time buyer), pelanggan atau nasabah loyal (loyal client), dan akhirnya menjadi pelanggan atau nasabah yang antusias (spiritual advocate), loyalitas nasabah akan terukur apila nasabah menjadi antusias menginformasikan keunggulan produk dan layanan BPRS HIK tanpa diminta khusus oleh BPRS HIK, semua hal itu tentunya diluar benefit yang BPRS HIK kasih kepada nasabah.

\section{KESIMPULAN}

Berdasarkan hasil analisis data terdapat pengaruh positif dan signifikan antara kompetensi sumber daya manusia terhadap tingkat loyalitas nasabah. Sebagaimana hasil uji $t$ diperoleh hasil $t_{\text {hitung }}$ sebesar 4,886 lebih besar dari $t_{\text {tabel }}$ yaitu 2,024 $(4,886>2,024)$ dan nilai signifikan lebih kecil dari $\alpha(0,000<0,05)$ sehingga dapat ditarik kesimpulan bahwa kompetensi sumber daya manusia berpengaruh positif dan signifikan terhadap tingkat loyalitas nasabah.

Berdasarkan hasil analisis yang telah dilakukan untuk mengetahui besarnya pengaruh kompetensi sumber daya manusia terhadap tingkat loyalitas nasabah dapat dilihat dari hasil koefisien determinasi. Hasilnya sebesar 0,386 atau 38,6\%. Hal ini menunjukkan bahwa variabel kompetensi sumber daya manusia $(\mathrm{X})$ berkontribusi sebesar $38,6 \%$ terhadap tingkat loyalitas nasabah (Y) dan sisanya $61,4 \%$ dipengaruhi oleh variabel lain yang tidak diteliti dalam penelitian ini. Walau pengaruh kompetensi sumber 
daya manusia terhadap tingkat loyalitas nasabah tidak besar, namun tetap saja kompetensi karyawan tetap harus diperhatikan demi kemajuan perusahaan, karena kompetensi merupakan bentuk layanan kepada nasabah, loyalitas akan terbangun apabila kompetensi digunakan di semua proses perjalanan nasabah menjadi nasabah yang antusias.

\section{REFERENSI}

Almasri, Muhammad Nazar. 2016. Manajemen Sumber Daya Manusia: Implementasi dalam Pendidikan Islam. Jurnal Penelitian Sosial Keagamaan, Vo. 19, No.2 JuliDesember.

Danupranata, Gita. 2013. Buku Ajar Manajemen Perbankan Syariah. Jakarta: Salemba Empat

Ghozali, Imam. 2006. Aplikasi Analisis Multivariate dengan Program SPSS. Semarang: Badan Penerbit Universitas Diponegoro.

------. 2013. Aplikasi Analisis Multivariate dengan Program IBM SPSS 21 Update PLS Regresi. Semarang: Badan Penerbit Universitas Diponegoro.

Kadir. 2015. Statistika Terapan Konsep, Contoh dan Analisis Data dengan program SPSS/Lisrel dalam penelitian. Jakarta: Rajawali Pers.

Lupiyoadi, Rambat. 2001. Manajemen Pemasaran Jasa teori dan Praktik. Jakarta: Salemba Empat.

Mandong, Indah S, Tumbel dan Tawas. 2017. Faktor-faktor yang Mempengaruhi Loyalitas Nasabah Pada PT. Bank BNI (Persero) Tbk Kantor Cabang Manado. Jurnal EMBA. Volume. 5 No.3 September.

Moeheriono. 2012. Pengukuran Kinerja Berbasis Kompetensi. Jakarta: Grafindo Persada.

Mussry, Jacky. et. all. 2007. MarkPlus On Marketing The Second Generation. Jakarta: PT. Gramedia Pustaka Utama.

Raharjo, Sahid. 2019. Panduan Lengkap Uji Regresi Sederhana dengan SPSS. Di akses pada 9 September 2019 dari www.spssindonesia.com/2017/03/uji-analisisregresi-linear-sederhana.

------. 2019. Cara Melakukan Uji t Parsial dalam Analisis Regresi dengan SPSS. Di akses pada 9 September 2019 dari www.spssindonesia.com/2014/02/-melakukan-ujitdengan-spss.

Rivai, Veithzal dan Sagala, Ella Jauvani. 2013. Manajemen Sumber Daya Manusia untuk Perusahaan dari Teori ke Praktik-Ed. 2-Cet. 4. Jakarta: Rajawali Pers.

Sergio Roman. 2003. The Impact of Ethical Sales Behavior on Customer Satisfaction, Trust and Loyalty to the Company: An Empirical Study in the Financial Service Industry, Journal of Marketing Management, Vol. 9. 
Rahmawati Akeda, Harun Masykur, \& Regita Cahyani

Sitanggang, Laurensius Marshall Sautlan. 2016. Sejak 2016, LPS sudah melikuidasi 90 BPR. Di akses pada 19 mei 2019 dari amp.kontan.co.id/news/sejak-2016-lpssudah-melikuidasi-90-bpr.

Sugiyono. 2017. Metode Penelitian Kuantitatif, Kualitatif dan R\&D. Bandung: Alfabeta. ------. 2009. Metode Penelitian Kuantitatif, Kualitatif dan R\&D. Bandung: Alfabeta.

Suherman, Ujang dan Tjiptono, Fandy ed. 2019. Strategi Pemasaran dalam Prespektif Perilaku Konsumen. Bogor: IPB Press.

Sumanto. 2014. Statistika Terapan. Jakarta: CAPS (Center Academic Publising Service).

Sutrisno, Edy. 2017. Manajemen Sumber Daya Manusia. Jakarta: Kencana.

Tho'in, Muhammad. 2016. Kompetensi Sumber Daya Manusia Bank Syariah Berdasarkan Prinsip-Prinsip Syariah Islam. Jurnal Ilmiah Ekonomi Islam. Volume. 02, No. 03.

Tjiptono, Fandy. 2000. Manajemen Jasa. Yogyakarta: Andi Offset.

Wijayanto, Kusuma. 2015. Pengaruh Kualitas Pelayanan terhadap Kepuasan dan Loyalitas Nasabah Bank. Jurnal Ekonomi Manajemen Sumber Daya. Vol. 17, No. 1, Juni. 